\title{
Financial Support Program for Small Farmers, and Its Impact on Local Food Security. Evidence from Indonesia
}

\author{
Endar Purnawan ${ }^{1, *}$, Gianluca Brunori ${ }^{1}$ (D) and Paolo Prosperi ${ }^{2}(\mathbb{D}$ \\ 1 Pisa Agricultural Economics Group (PAGE), Department of Agriculture Food and Environment, \\ University of Pisa, 56124 Pisa, Italy; gianluca.brunori@unipi.it \\ 2 Mediterranean Agronomic Institute of Montpellier (CIHEAM-IAMM), UMR Moisa, Univ Montpellier, \\ CIHEAM-IAMM, CIRAD, INRAE, IRD, L'Institut Agro, 34093 Montpellier, France; prosperi@iamm.fr \\ * Correspondence: epurnawan2@gmail.com
}

check for updates

Citation: Purnawan, E.; Brunori, G.; Prosperi, P. Financial Support Program for Small Farmers, and Its Impact on Local Food Security. Evidence from Indonesia. Horticulturae 2021, 7, 546. https:/ / doi.org/10.3390/horticulturae7120546

Academic Editors: Riccardo Testa, Giuseppina Migliore,

Giorgio Schifani and József Tóth

Received: 6 October 2021

Accepted: 30 November 2021

Published: 3 December 2021

Publisher's Note: MDPI stays neutral with regard to jurisdictional claims in published maps and institutional affiliations.

Copyright: (c) 2021 by the authors. Licensee MDPI, Basel, Switzerland. This article is an open access article distributed under the terms and conditions of the Creative Commons Attribution (CC BY) license (https:// creativecommons.org/licenses/by/ $4.0 /)$.

\begin{abstract}
This paper addresses the implementation of the Kawasan Mandiri Pangan (KMP) program, a microfinance program for farmer groups, assessing whether the program affects farmers' decisions concerning production, marketing, and consumption or not, and its impacts on household food security along three dimensions: food availability, food access, and food utilization. Based on a qualitative and theory of change mixed-methods analysis, which uses interviews and focus group discussions (FGDs), this research sheds light on the program's success among two groups of farmers. Both groups experienced improved productivity and increased food availability, but only one group sustained the program. The results indicate that the program has not affected the commercialization of any particular crop, where the crop's best selling price, relationships, and commitments are factors that affect the farmers' marketing decisions. Other findings show how food access at the household level increased when the crop's selling price was reasonable, while food utilization was influenced predominantly by local wisdom. Taken together, the research findings highlight the importance of the capability of the management, the commitment of the members, and the supervision of the agricultural extension agents. There is a need for a locally owned enterprise to absorb agricultural products and maintain the selling price of crops, which is the primary driver of food accessibility and utilization at the household level.
\end{abstract}

Keywords: financial access; small family farms; food security; Indonesia

\section{Introduction}

The agricultural sector in Indonesia plays a crucial role in the economy by employing $40 \%$ of its population and contributing to more than 15\% of GDP [1]. More than 27 million families run family farms, with the total number of family members close to 100 million [2]. Of this total, 93\% were small family farms, with one in five of them trapped in poverty [3]. Despite being economically active, these poor families experience poverty and food insecurity. One of the strategies implemented to improve food security in the rural community or for small farmers is through a microfinance program. A number of studies have carefully measured the impact of microfinance programs on household food security, such as Hidayat and Nugraha (2011) [4] on the fulfillment of household food needs in Indonesia, Baihaqi (2013) [5] on the food shortages experienced by low-income families in Indonesia, Darwis et al. (2014) [6] on the cases of staple food shortages in Indonesia, Bidisha et al. (2017) [7] on household incomes and dietary diversity in Bangladesh, Meador and Fritz (2017) [8] on the empowerment of women and household food security in Uganda, and Adnan Shahid and Bohara (2020) [9] on household food consumption measures in Nepal.

The Sekayam subdistrict, located in the Sanggau Regency, Indonesia, was selected as an illustrative case study. It is an inter-country border area between Indonesia and Malaysia with an area of $841.01 \mathrm{~km}^{2}$ and a total population amounting to 35,141 people [2]. The community in the border area faces some challenging conditions in terms of attaining 
food security. Food prices in Indonesia were recorded to be higher than in neighboring countries [10], especially in the border areas between countries. This scenario is exacerbated by a common problem that occurs in border areas, which is a lack of access to infrastructure that further limits food distribution. As a consequence, the price of food commodities has escalated.

As a result, the Indonesian Ministry of Agriculture issued a set of regulations in 2014 (number: 06/Permentan/OT.140/1/2014), which included the Desa Mandiri Pangan (DMP) guidelines. The scope of DMP activities included KMP - a target of the program is inter-country border area communities. The general objective of the KMP program is to empower poor/food insecure people, helping them to become self-reliant. It also includes the following outputs: the distribution of social assistance funds, and the provision of training/assistance for affinity groups. The social assistance funds are channeled to farmer groups and distributed to their members in the form of loan. The expected outcomes are an increase in income, higher purchasing power among the people, and better access to food, all of which would contribute towards improving food security within the community.

This paper is aimed at addressing the following research question: what is the impact of the KMP program on local food security, and, in particular, how has it affected food availability, food access, and food utilization for households within the community? The primary aims are: (1) to explore the implementation of the KMP program in the Sekayam subdistrict, (2) to determine the impact of the KMP program on farmers' decisions as they concern production, marketing, and consumption, and (3) to evaluate the impacts of the program through an analysis of household food security among family farmers who have participated in the KMP program based on their experience in three areas, namely, food availability, food accessibility, and food utilization.

\section{Literature Review}

Microfinance (MFI) is defined by Robinson (2002) [11] as small-scale financial services, especially savings and loans provided to small farmers, fishers, and pastoralists or those who run small businesses that produce, recycle, repair, and sell goods, provide minor services, work on a commission basis, or earn an income from renting agricultural machinery at the local level, both in rural and urban settings.

According to Morris and Barnes (2015) [12], providers of MFI should consider the feasibility of providing individual loan products to participants who were diligent in repaying their group loans. These individuals seek to "graduate" to larger loans with collateral to secure the loan. This program is not a microfinance program, however, where the term 'microfinance' denotes the entire range of financial services (e.g., savings, money transfer, insurance, production and investment credit, and housing finance), the upgrade of skills, and entrepreneurial development, which are vital to escape poverty [13]. Rather, the scope of the program is narrower, and it simply provides microcredit for farmers, offering small loans for short durations with repayments beginning as quickly and as frequently as possible [14].

A study by the Consultative Group to Assist the Poor (CGAP) (see Mahajan, 2005) [14] revealed that only about 100 out of 10,000 MFI programs across the globe were financially self-sufficient. Thus, the dual promise that microcredit can serve the very poor in a financially sustainable manner is not borne out in practice. Experience reveals that either one of these two mutually contradictory goals can be achieved, but not both together [14].

A key issue is whether the provision of MFI to small farmers influences their decisions regarding production and marketing or crop commercialization. Most decisions related to farm production are influenced by the characteristics of the farmers in their community and the commodity's selling price at any given moment. Finnis (2006) [15] asserted that constant market demand is one of the reasons that make some crops good crops to cultivate during times of environmental uncertainty, due to their good selling price and the certainty of income from the crop. The same was reported by Baker (1995) [16] for crop decisions and cassava cultivation in Gambia (see Rigg, 1987) [17]. 
Crop commercialization cannot be understood solely in terms of external pressures, such as government policies [18-20]. Instead, it is necessary for researchers to consider local-level agricultural decision making [21], including the experiences and perspectives highlighted by Attwood [22] (p. 16), who referred to small farmers as "enterprising peasant families". Crop commercialization and intensification can be the result of conscious decisions based on individual and household aspirations [15]. Changes in local-level farming and crop commercialization are referred to as an "indigenous intensification of cultivation", a process that "takes place without specific external development impetus", such as government practices, NGO projects, as well as new international trade policies and rulings $[15,18,23]$.

\section{Materials and Methods}

The qualitative data gathered in this study were analyzed using inductive and descriptive analyses to obtain in-depth and accurate results [24]. A non-probability sampling technique was employed, with the purposive sampling of a total of 34 informants, who comprised six key informants (one food security officer, three agricultural extension workers, and two coordinators of farmer groups), 15 participant farmers, four non-participant farmers, and nine informants for three forum group discussions (FGDs) (which consisted of farmers and other key informants). We collected primary data through FGDs and in-depth interviews, and we assessed a range of documents to obtain the secondary data. Data collection was conducted between April and August of 2019. This present study measured food security by assessing food availability, food access, and food utilization. We used several indicators to assess both food availability and food accessibility at the household level, and we used modified household dietary diversity score (HDDS) indicators and several additional questions to explore household food utilization. The indicators that were used during the interview and FGD sessions (Table 1) facilitated an exploration of the implementation of the KMP program, while concurrently helping us look into food availability, food accessibility, and food utilization within the community, with the informants telling us about their experience in their own words.

The HDDS indicators were used, which were modified from those used in the Food and Nutrition Technical Assistance (FANTA) project, which determined if a household consumed food from the seven food groups (see Swindale and Bilinsky, 2006) [25]. (FANTA was a cooperative agreement funded by USAID. The project was managed by FHI 360, a nonprofit human development organization dedicated to improving lives in lasting ways by advancing integrated, locally driven solutions.) Data for the HDDS indicators were gathered through the use of qualitative interview questions regarding the food items used in the participant's household, the relative amount used in a month, and where they obtained their food items. We asked participants to determine their household consumption over a one-month period, which we found to be more reliable than asking them to select a specific day. In deciding if a food item was often consumed in the household, a 14-day standard was used: if the item was consumed at least once a day on less than 14 days of the month, this signified that its use was uncommon (0), while more than 14 days of food consumption indicated common household consumption (1). The HDDS thresholds used in this study were $<4.5=$ low dietary diversity, $4.5-6=$ medium dietary diversity, and $6+=$ high (good) dietary diversity. Table 2 lists the HDDS thresholds proposed by the International Food Policy Research Institute (IFPRI) that were used in this study. 
Table 1. Indicators used during interviews and FGD sessions.

\begin{tabular}{|c|c|c|c|}
\hline \multicolumn{4}{|c|}{ Indicators } \\
\hline No. & \multicolumn{3}{|c|}{ Farmer } \\
\hline 1. & $\begin{array}{l}\text { Information related to the respondent } \\
\text { and the household }\end{array}$ & 10. & $\begin{array}{l}\text { Experiences of difficulty accessing food } \\
\text { (no money to buy food) and strategies } \\
\text { on how to deal with such situation }\end{array}$ \\
\hline 2. & $\begin{array}{l}\text { Duration of stay in the } \\
\text { community/place }\end{array}$ & 11. & $\begin{array}{l}\text { Method and fuels used in preparing } \\
\text { food for consumption }\end{array}$ \\
\hline 3. & $\begin{array}{l}\text { Land for farming, plant types, and } \\
\text { amount of annual harvest for each crop }\end{array}$ & 12. & Involvement in the KMP program \\
\hline 4. & $\begin{array}{l}\text { Crops consumed, sold, and used for } \\
\text { agricultural inputs }\end{array}$ & 13. & Use of aid/loan \\
\hline 5. & Current family income per month & 14. & $\begin{array}{l}\text { Loan application requirements and } \\
\text { obligations of borrower }\end{array}$ \\
\hline 6. & Monthly income five years ago & 15. & $\begin{array}{l}\text { Obstacles faced in running the } \\
\text { agriculture (program) }\end{array}$ \\
\hline 7. & $\begin{array}{l}\text { Money spent on food and } \\
\text { agricultural inputs }\end{array}$ & 16. & $\begin{array}{l}\text { The differences before and after the } \\
\text { program, in terms of food access and } \\
\text { food utilization }\end{array}$ \\
\hline 8. & $\begin{array}{l}\text { Water sources for consumption } \\
\text { and agriculture }\end{array}$ & 17. & $\begin{array}{l}\text { Improvements needed for this program } \\
\text { or a similar agricultural program }\end{array}$ \\
\hline 9. & $\begin{array}{l}\text { Determining factors for choosing food to } \\
\text { consume and special moments for food }\end{array}$ & & \\
\hline No. & \multicolumn{3}{|c|}{ Agricultural Extension Worker and Chief of Farmer Group } \\
\hline 1. & $\begin{array}{l}\text { Activities and outcomes of the KMP } \\
\text { program }\end{array}$ & 4. & Impact of the KMP program on farmers \\
\hline 2. & $\begin{array}{l}\text { Procedures and obligation of the } \\
\text { participants }\end{array}$ & 5. & $\begin{array}{l}\text { Other program(s) participated in by } \\
\text { farmers }\end{array}$ \\
\hline 3. & $\begin{array}{l}\text { Obstacles and problems in } \\
\text { implementing the KMP program }\end{array}$ & 6. & $\begin{array}{l}\text { Suggestion(s) for improving the } \\
\text { program }\end{array}$ \\
\hline
\end{tabular}

Table 2. HDDS thresholds proposed by IFPRI.

\begin{tabular}{cc}
\hline HDDS & Profile \\
\hline$<4.5$ & Low dietary diversity \\
$4.5-6$ & Medium dietary diversity \\
$6+$ & High (good) dietary diversity \\
\hline
\end{tabular}

The stages of data analysis in this study adhered to that prescribed by Neuman, as illustrated below (Figure 1).

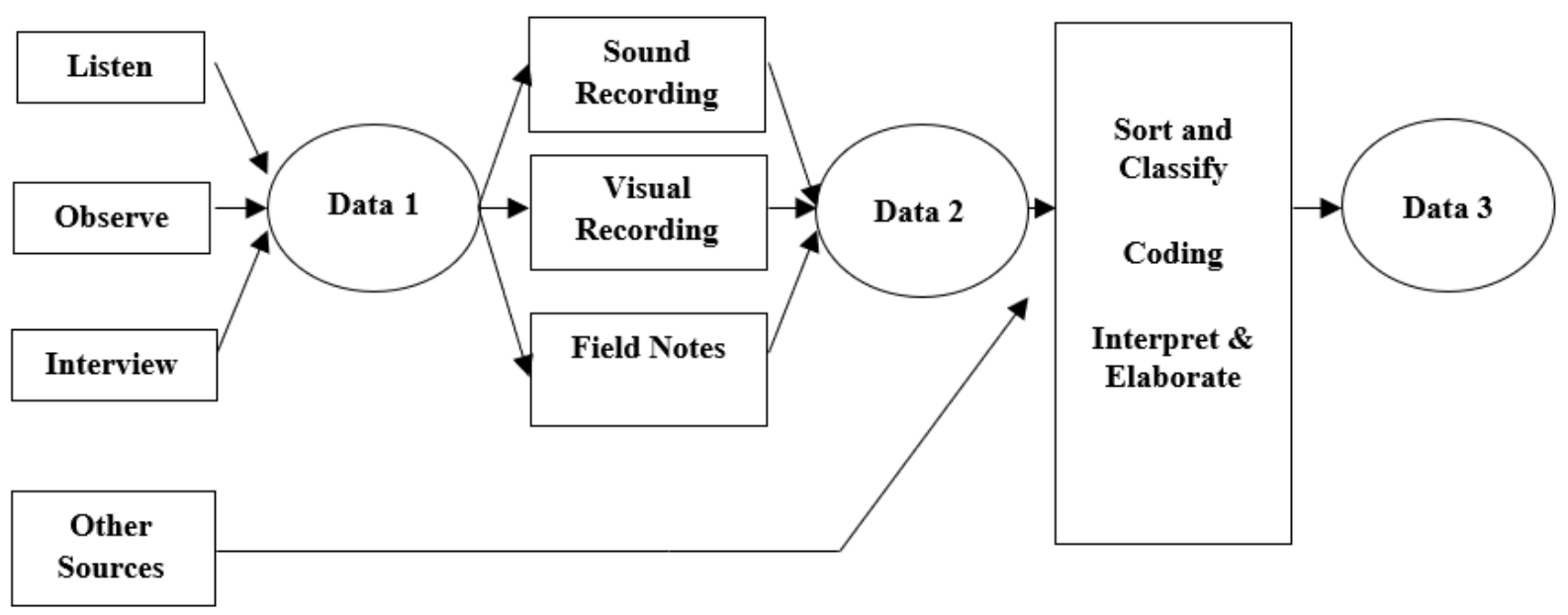

Collect Data

Analyze Data

Figure 1. Data analysis process (modified from [24]). 
The theory of change was also employed in this paper as a tool to creatively and productively blend our analysis with other evaluation methods, meaning that it could be applied at various levels to help us yield deeper insights [26]. In particular, these mixed methods generate the most impactful, "most significant change" stories [27]. The term "theory of change" comes from the field of program assessment. It is the process of creating a model that depicts the underlying logic, assumptions, influences, causal relationships, and projected consequences of a development project. This model may be validated by comparing it to the actual process and outcomes of the intervention [28-30]. The theory of change can be used in conjunction with other data collection and analysis methods. In this way, it is a flexible instrument that encourages analytical rigor, learning, and cost effectiveness. The theory of change allows us to question programs at all levels, including as they regard specific investments, and at community, family, and individual levels. For example, to challenge an impact investing program, we should ask: how much do impact investments help the poor and the marginalized? [26]. The theory of change is an appropriate strategy for this study since it serves the objectives of monitoring and evaluating [31]. As a theoretical framework, the theory of change has been used by Adekunle and Fatunbi [32], Mayne and Johnson [33], de Silva et al. [34], Schierhout et al. [35], and Fullan [36] in the fields of agriculture, medicine and healthcare, as well as education.

There are three communities involved in the KMP program in the research area (the Sekayam subdistrict), namely, the Ruis hamlet, the Kenaman hamlet, and the Berungkat hamlet (Table 3). These farmers planted any commodity with good selling prices that would sustain their income. They varied their crops to deal with the price volatility that could affect their income. On average, they managed 2.68 ha of farm field per household (data were obtained from all farmers, who participated in the study as informants). They mostly relied on family labor, extended family, and the community for farming activities.

Table 3. Population and farmers in the Ruis, Kenaman, and Berungkat hamlets.

\begin{tabular}{ccccc}
\hline Hamlet & Population & Tribe & Farmer Group & $\begin{array}{c}\text { Farmer } \\
\text { (Members) }\end{array}$ \\
\hline Ruis & 410 & Malay & 3 & 78 \\
Kenaman & 1370 & Dayak, Malay, & 7 & 166 \\
Berungkat & 1018 & Javanese & 6 & 153 \\
\hline Total & 2798 & & 16 & 397 \\
\hline
\end{tabular}

\section{Results and Discussion}

\subsection{The Implementation of the KMP Program}

The KMP program in the study area was carried out in five stages ( 5 years), which began in 2013. The program covered the preparation, growth, and development stages, and also dealt with farmers' independence and exit strategies. The first year of implementing the program failed due to floods that struck the agricultural areas for 5 days in December 2013, which was followed by a prolonged drought for 4 months in early 2014. The social assistance fund ended with the issuance of statements of non-repayment of loans by borrowers due to natural disasters. In the next year, there were two groups participating in the program, the Karir group and Sumber Rejeki group. In the Karir group, the aid was distributed 31 times to farmers in 2015 (see Table 4), whose poor yield was evident by the state of their fields. They failed to return the loans, however, and so the roll was discontinued for other members. Meanwhile, the farmers in Sumber Rejeki group succeeded in managing the aid in accordance with the plan. Since the members repaid the loan, the roll was continued to the other members. A total 24 members of the group applied for a loan from 2015 to 2018 (Tables 5-7), and most of them re-applied for a loan (see the timeline in the Figure 2 below). 
Table 4. Loan distribution among the Karir group 2015-2016 (2015 rates USD $1=$ IDR 13,795 and EUR 1 = IDR 15,070).

\begin{tabular}{|c|c|c|c|}
\hline No. & Participants & $\begin{array}{l}\text { Amount of Loan } \\
\text { (IDR/USD/EUR) }\end{array}$ & Activity \\
\hline 1 & Farmer 1 & $15,000,000 / 1087.3 / 995.4$ & Goat livestock \\
\hline 2 & Farmer 2 & $14,000,000 / 1014.9 / 929$ & Banana flour processing \\
\hline 3 & Farmer 3 & $5,000,000 / 362.5 / 331.8$ & Oil palm plantation \\
\hline 4 & Farmer 4 & $5,000,000 / 362.5 / 331.8$ & Oil palm plantation \\
\hline 5 & Farmer 5 & $5,000,000 / 362.5 / 331.8$ & Banana plantation \\
\hline 6 & Farmer 6 & $5,000,000 / 362.5 / 331.8$ & Oil palm plantation \\
\hline 7 & Farmer 7 & $7,000,000 / 507.4 / 464.5$ & Pepper plantation \\
\hline 8 & Farmer 8 & $8,000,000 / 579.9 / 530.9$ & Pepper plantation \\
\hline 9 & Farmer 9 & $5,000,000 / 362.5 / 331.8$ & Pepper plantation \\
\hline 10 & Farmer 10 & $5,000,000 / 362.5 / 331.8$ & Pepper plantation \\
\hline 11 & Farmer 11 & $5,000,000 / 362.5 / 331.8$ & Motorbike \\
\hline 12 & Farmer 12 & $5,000,000 / 362.5 / 331.8$ & Oil palm plantation \\
\hline 13 & Farmer 13 & $8,000,000 / 579.9 / 530.9$ & Oil palm plantation \\
\hline 14 & Farmer 14 & $5,200,000 / 376.9 / 345.1$ & Oil palm plantation \\
\hline 15 & Farmer 15 & $5,000,000 / 362.5 / 331.8$ & Oil palm plantation \\
\hline 16 & Farmer 16 & $5,200,000 / 376.9 / 345.1$ & Horticultural vegetable farming \\
\hline 17 & Farmer 17 & $5,260,000 / 381.3 / 349.0$ & Chicken livestock \\
\hline 18 & Farmer 18 & $3,400,000 / 246.5 / 225.6$ & Horticultural vegetable farming \\
\hline 19 & Farmer 19 & $5,000,000 / 362.5 / 331.8$ & Pepper plantation \\
\hline 20 & Farmer 20 & $5,000,000 / 362.5 / 331.8$ & Horticultural vegetable farming \\
\hline 21 & Farmer 21 & $3,000,000 / 217.5 / 199.1$ & Horticultural vegetable farming \\
\hline 22 & Farmer 22 & $3,400,000 / 246.5 / 225.6$ & Rice farming \\
\hline 23 & Farmer 23 & $3,400,000 / 246.5 / 225.6$ & Rice farming \\
\hline 24 & Farmer 24 & $1,800,000 / 130.5 / 119.4$ & Horticultural vegetable farming \\
\hline 25 & Farmer 25 & $5,710,000 / 413.9 / 378.9$ & Horticultural vegetable/rice farming \\
\hline 26 & Farmer 26 & $3,350,000 / 242.8 / 222.3$ & Rice farming \\
\hline 27 & Farmer 27 & $6,000,000 / 434.9 / 398.1$ & Goat livestock \\
\hline 28 & Farmer 28 & $4,200,000 / 304.5 / 278.7$ & Rice farming \\
\hline 29 & Farmer 29 & $6,000,000 / 434.9 / 398.1$ & Pepper plantation \\
\hline 30 & Women Group & $12,280,000 / 890.2 / 814.9$ & Duck livestock \\
\hline \multirow[t]{2}{*}{31} & Karir group & $25,000,000 / 1812.3 / 1658.9$ & Cattle activities \\
\hline & Total & $200,000,000 / 14,498 / 13,27$ & 71.4 \\
\hline
\end{tabular}

Table 5. Loan distribution among the Sumber Rejeki group 2014-2015 (2014 rates USD $1=$ IDR 12,440 and EUR 1 = IDR 15,746).

\begin{tabular}{|c|c|c|c|}
\hline No. & Participants & $\begin{array}{l}\text { Amount of Loan } \\
\text { (IDR/USD/EUR) }\end{array}$ & Activity \\
\hline 1 & Farmer 1 & $5,000,000 / 401.9 / 317.5$ & Rice farming \\
\hline 2 & Farmer 2 & $5,000,000 / 401.9 / 317.5$ & Rice farming \\
\hline 3 & Farmer 3 & $5,000,000 / 401.9 / 317.5$ & Rice farming \\
\hline 4 & Farmer 4 & $5,000,000 / 401.9 / 317.5$ & Rice farming \\
\hline 5 & Farmer 5 & $5,000,000 / 401.9 / 317.5$ & Maintaining vehicle \\
\hline 6 & Farmer 6 & $5,000,000 / 401.9 / 317.5$ & Pepper plantation \\
\hline 7 & Farmer 7 & $5,000,000 / 401.9 / 317.5$ & Pepper plantation \\
\hline 8 & Farmer 8 & $5,000,000 / 401.9 / 317.5$ & Pepper plantation \\
\hline 9 & Farmer 9 & $5,000,000 / 401.9 / 317.5$ & Pepper plantation \\
\hline 10 & Farmer 10 & $5,000,000 / 401.9 / 317.5$ & Pepper plantation \\
\hline \multicolumn{2}{|c|}{ Total } & $50,000,000 / 4019.3 / 317$ & \\
\hline
\end{tabular}


Table 6. Loan distribution among the Sumber Rejeki group 2016-2017 (2016 rates USD $1=$ IDR 13,436 and EUR 1 = IDR 14,722).

\begin{tabular}{cccc}
\hline No. & Participants & $\begin{array}{c}\text { Amount of Loan } \\
\text { (IDR/USD/EUR) }\end{array}$ & Activity \\
\hline 1 & Farmer 7 & $5,000,000 / 372.1 / 339.6$ & Pepper plantation \\
2 & Farmer 9 & $5,000,000 / 372.1 / 339.6$ & Pepper plantation \\
3 & Farmer 1 & $5,000,000 / 372.1 / 339.6$ & Pepper plantation \\
4 & Farmer 11 & $5,000,000 / 372.1 / 339.6$ & Pepper plantation \\
5 & Farmer 12 & $5,000,000 / 372.1 / 339.6$ & Pepper plantation \\
6 & Farmer 13 & $5,000,000 / 372.1 / 339.6$ & Pepper plantation \\
7 & Farmer 14 & $5,000,000 / 372.1 / 339.6$ & To make a home kitchen \\
8 & Farmer 15 & $5,000,000 / 372.1 / 339.6$ & Pepper plantation \\
9 & Farmer 5 & $5,000,000 / 372.1 / 339.6$ & Rice farming \\
10 & Farmer 16 & $4,500,000 / 334.9 / 305.7$ & Rice farming \\
11 & Farmer 8 & $5,000,000 / 372.1 / 339.6$ & Rice farming \\
12 & Farmer 17 & $5,000,000 / 372.1 / 339.6$ & Rice farming \\
13 & Farmer 18 & $5,000,000 / 372.1 / 339.6$ & Rice farming \\
14 & Farmer 11 & $5,000,000 / 372.1 / 339.6$ & Rice farming \\
\hline
\end{tabular}

Table 7. Loan distribution among the Sumber Rejeki group 2018 (2018 rates USD $1=$ IDR 14,481 and EUR $1=$ IDR 16,560).

\begin{tabular}{cccc}
\hline No. & Participants & $\begin{array}{c}\text { Amount of Loan } \\
\text { (IDR/USD/EUR) }\end{array}$ & Activity \\
\hline 1 & Farmer 7 & $5,000,000 / 345.3 / 301.9$ & Pepper plantation \\
2 & Farmer 9 & $5,000,000 / 345.3 / 301.9$ & Pepper plantation \\
3 & Farmer 1 & $5,000,000 / 345.3 / 301.9$ & Pepper plantation \\
4 & Farmer 11 & $5,000,000 / 345.3 / 301.9$ & Pepper plantation \\
5 & Farmer 12 & $5,000,000 / 345.3 / 301.9$ & Pepper plantation \\
6 & Farmer 13 & $5,000,000 / 345.3 / 301.9$ & Pepper plantation \\
7 & Farmer 14 & $5,000,000 / 345.3 / 301.9$ & Health treatment \\
8 & Farmer 15 & $5,000,000 / 345.3 / 301.9$ & Pepper plantation \\
9 & Farmer 19 & $5,000,000 / 345.3 / 301.9$ & Pepper plantation \\
10 & Farmer 20 & $5,000,000 / 345.3 / 301.9$ & Pepper plantation \\
11 & Farmer 5 & $5,000,000 / 345.3 / 301.9$ & Rice farming \\
12 & Farmer 16 & $5,000,000 / 345.3 / 301.9$ & Rice farming \\
13 & Farmer 8 & $5,000,000 / 345.3 / 301.9$ & Rice farming \\
14 & Farmer 17 & $5,000,000 / 345.3 / 301.9$ & Rice farming \\
15 & Farmer 18 & $5,000,000 / 345.3 / 301.9$ & Rice farming \\
16 & Farmer 11 & $5,000,000 / 345.3 / 301.9$ & Rice farming \\
17 & Farmer 21 & $5,000,000 / 345.3 / 301.9$ & Rice farming \\
18 & Farmer 22 & $5,000,000 / 345.3 / 301.9$ & Rice farming \\
19 & Farmer 23 & $5,000,000 / 345.3 / 301.9$ & Rice farming \\
20 & Farmer 24 & $5,000,000 / 345.3 / 301.9$ & Rice farming \\
\hline & & $100,000,000 / 6905.6 / 6038.6$ & \\
\hline & & & \\
\hline
\end{tabular}

4.1.1. Was the Program Theory Valid, Appropriate, Relevant, and Accurate? Did Change Actually Occur in the Ways the Government Had Expected?

One of the key points in the KMP's theory of change was the distribution of social assistance funds, which were distributed in the form of loans to farmers, instead of involving MFI organizations, such as banks and credit unions. The loan acquisition process was easy as the farmers only had to submit some documents to the LKK, such as a copy of the family card and identity card. The farmers were able to acquire a loan worth below IDR 5 million without collateral, and above IDR 5 million with collateral and after repayment of the initial loan. Morris and Barnes (2015) [12] argue that MFI organizations should explore 
offering individual loans to individuals who paid back their group loans on time, helping them "graduate" to bigger loans with collateral.

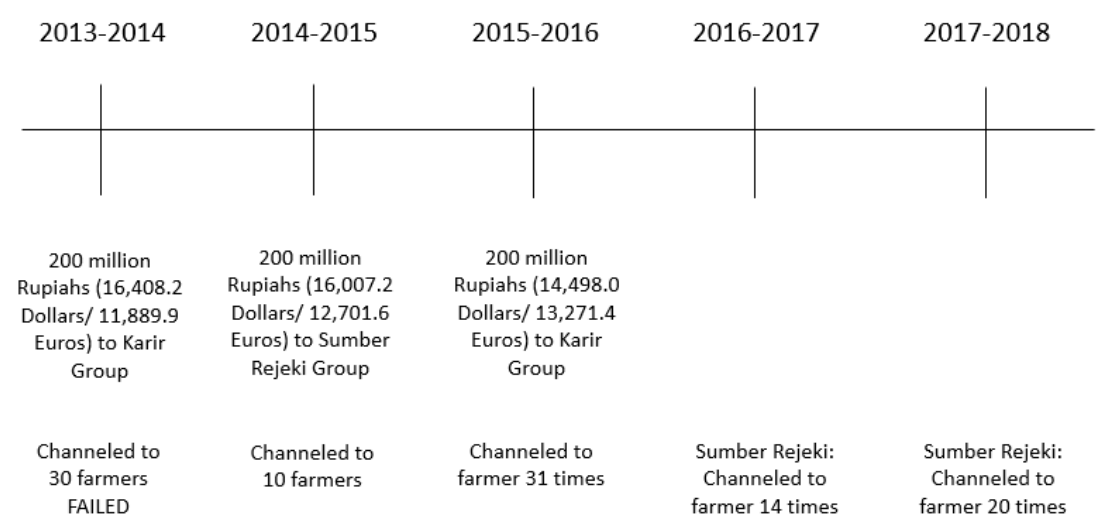

Figure 2. KMP program implementation timeline.

In the KMP program, farmers were expected to use the loan for farming activities or for farming-related business. Accordingly, most farmers spent the loan from the program on their farms, purchasing farming tools, fertilizers, pesticides, and seeds, as well as spending money on clearing land. Some farmers used the loan for other needs, such as maintaining the vehicles that they used for harvesting crops, health needs, building houses, and buying a motorcycle for non-farm income purpose (see Tables 4-7). Some points gathered from the FGD session in Berungkat are as follows: farmers had better access to food with better income, bought some necessities, and saved some money.

Based on the explanation given above, a change in the communities was caused by the KMP program, with the establishment of MFI for farmers and easy access to loans, as expected. The flexibility of loan use and its dynamic impact on households exceeded the program's theory of change (see Figure 3). Despite only being intended to increase access to food and farmers' purchasing power to enhance their food security, the microloan had helped farmers meet multiple needs, such as paying for the education of their children and their healthcare, contributing to family savings, and improving their assets. Clearly, change dynamics were noted due to deployment of the program (see Figure 3).

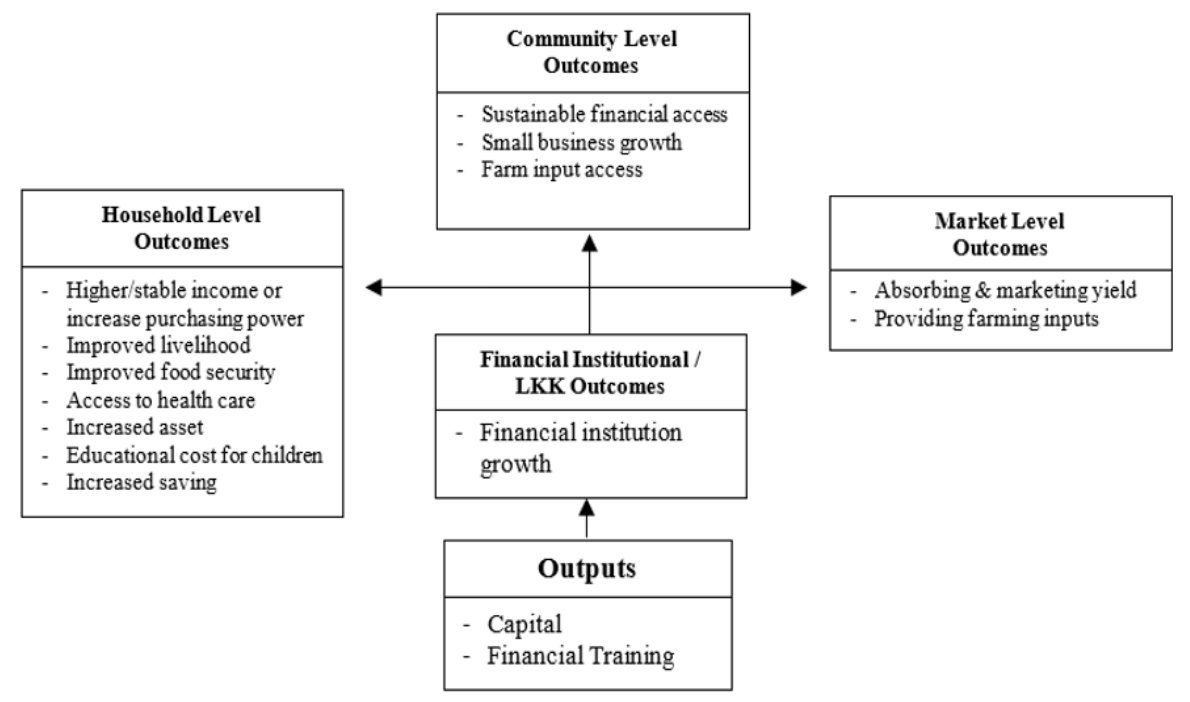

Figure 3. Change dynamics caused by the KMP program.

In the Karir group, the borrowers for each last loan did not return the money, and the management did not make any effort to collect the loans due to the location of the recipients of the aid, who were in three villages in distant hamlets. In the Sumber Rejeki 
group, however, the fund was repaid in full, as the program managers had expected. They also provided farming inputs, such as fertilizer, to their members annually from 2015 to 2018 and planned to absorb/market crops on behalf of farmers in the future. Thus, the change dynamic of the program portrayed in Figure 3 suited the Sumber Rejeki group, due to the KMP program's impact at the household, community, and market levels. In this group, the capability and the commitment of the group members were assessed before sanctioning the loan to make sure that they were able to repay the loan. This led to the following question: "how can the very poor access this microcredit if they lack the capability to repay the loan?" As Mahajan [14] mentioned, the dual promise that microcredit may benefit the very poor while also being financially viable is not fulfilled in practice. These two seemingly opposing objectives can be attained separately, but not simultaneously [14].

\subsubsection{Are There Unforeseen Actors and Factors That Promote or Impede Change?}

Some particular conditions prevented some actors from performing exceptionally, and they are as follows. Firstly, extension workers lacked control when deploying the program because they were rotated four times over the program's duration. Secondly, there was a lack of training prior to the distribution of the fund. Both of these obstacles caused the program to not run as expected. Thirdly, there was a lack of trust among the members, because the Karir group consisted of three subgroups of farmers, with two groups in the Ruis hamlet and a group in Kenaman hamlet. Finally, the geographic distribution of these groups across the hamlets influenced the management to provide extra time and money to help them control their members. This, however, did not occur in the LKK in Sumber Rejeki as there was only a single group in the Berungkat hamlet.

Other factors that impeded the expected change are as follows. First, climate conditions harmed farming activities, with a flood in the monsoon season at the end of 2013 and a subsequently long drought season in early 2014. Second, instability in the selling price of cash crops after 2017 decreased the income of the farmers. This impacted their ability to access farming inputs, which translated into decreased farm productivity and reduced their income from farming. Hence, the financial aid did have an impact on their family, but it was only temporarily due to low selling prices. Figure 4 shows changes in the income of farmers from 2014 to 2019 due to the selling price volatility of agricultural crops.

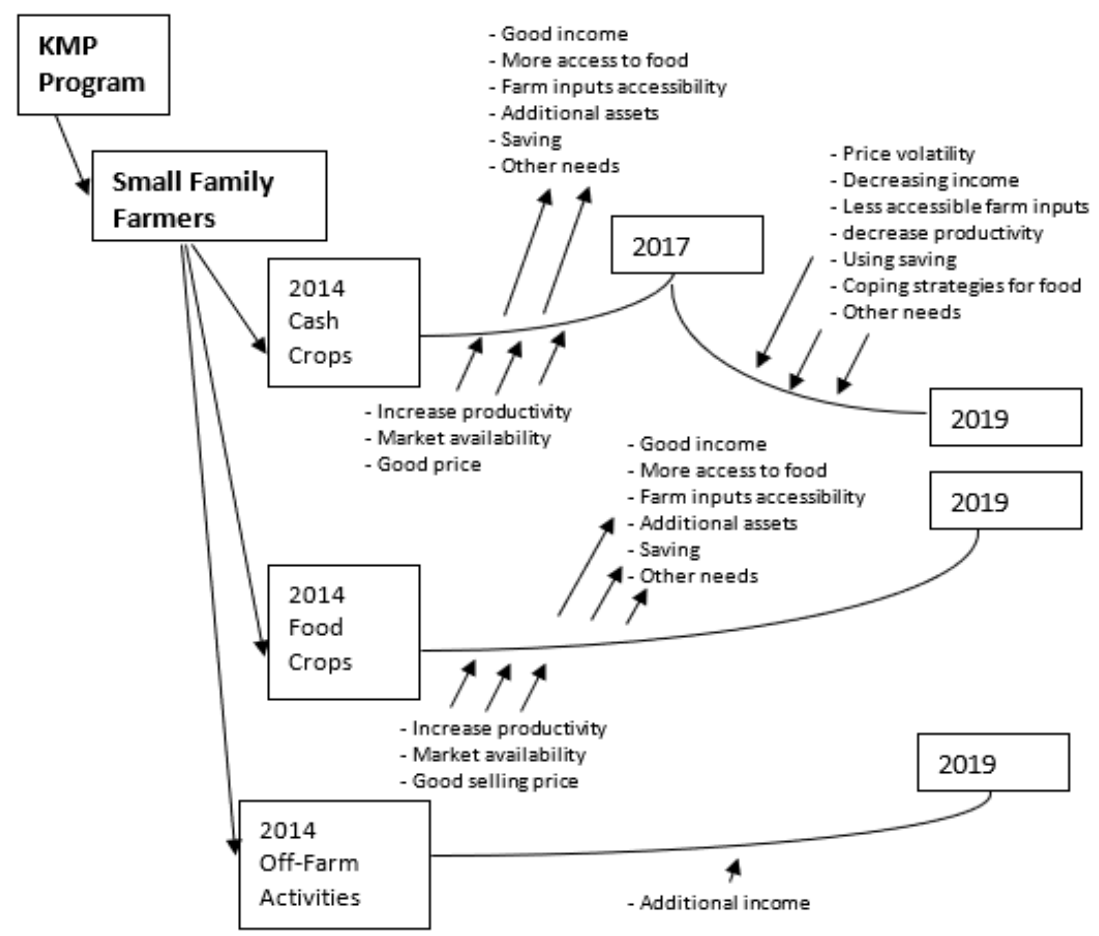

Figure 4. Changes in the income of farmers from 2014 to 2019. 


\subsection{Did the Microloan Affect Farmers' Production, Marketing, and Consumption Decisions?}

In the Berungkat hamlet, most of the farmers cultivated cash crops, such as rubber, pepper, and oil palm, along with rice and vegetable for self-provision. At the start of this program in this hamlet, the price of rubber was low. Thus, the farmers used the loan to grow pepper plants and/or oil palm. Then, as claimed by a farmer in Kenaman, where most farmers in this hamlet grew food crops, such as rice and vegetable, "I managed vegetable farming and planned to focus only on vegetable farming, in 2015, I borrowed 3 million rupiah [IDR 3 million] to support vegetable farming activities. We used all the money to buy agricultural inputs, such as seeds and fertilizers" (Farmer 6, Kenaman). This is in keeping with what Finnis [15], Baker [16], and Rigg [17] discovered, i.e., that most farm production decisions were impacted by the characteristics of farmers and current commodity prices.

The instances above also reveal the absence of intervention by the program in the commercialization of specific crops. The farmers were free to choose any kind of crop to cultivate using the loan from this program. External pressures, such as government policies, cannot fully explain crop commercialization [18-20]. Instead, agricultural commercialization and intensification can be deliberate decisions driven by personal and family goals [15]. The indigenous intensification of agricultural products is a process that occurs "without explicit external development impetus" $[15,18,23]$. The price was the main factor that affected the farmers' marketing decisions, along with relationships and other commitments. A farmer informed us that if they could reach the border line between the two countries to gain a better price, they would do it. In the 2000s, when the border door between Indonesia and Malaysia was still open and free, selling pepper and cocoa between the countries was free, too. Therefore, farmers used to sell these goods directly at the border gate to gain a better price. Now this is no longer possible, and farmers sell pepper to middlemen. The last time that they sold directly at the border was 2013, when the price of pepper was still reasonable. Approximately $30 \%$ of the farmers who participated in this study stated that they sold their crops wholesale in other villages to obtain a better price. Another farmer added that he always sold his rubber to one person due to the close interaction between them. "We always sell our rubber to a middleman in this hamlet, he is our relative and we always borrow goods from him as he manages a small grocery" (Farmer 11, Ruis).

The other factors include a wide range of connections with people to whom they could sell their products and the availability of a traditional market, where farmers can market their crops, especially vegetable farmers. As one farmer said, "Rice is sold directly to consumers, relatives, and colleagues. Mustard greens, kangkong, and spinach are sold to traditional markets in Balai Karangan. We have 15 customers who sell the products to their consumers. Every time we harvest, we immediately deliver the produce to the retailers" (Farmer 6, Kenaman). As many as $27 \%$ of the total respondents stated the same thing-they, too, sell rice directly to consumers, relatives, or colleagues. Based on the depiction above, there is no strong evidence that closely ties the KMP program to the marketing decisions made by the farmers.

Consumption decisions were very much influenced by local wisdom, such as not changing food consumption too much even after gaining extra money, but instead saving the money for future needs. "Actually, the opportunity to access better food was very wide open, but people in this community are not accustomed to changing their simple eating patterns; neither excessive nor deficient. Many other needs must be met, such as education cost, agricultural inputs, loan, and other daily costs (gas, electricity, gasoline, etc.). They need to save money for different needs in the future and to survive when the selling price of agricultural commodities is lower" (a participant in the FGD in Ruis). The habit of these farmers who do not spend much on food even with a good income is reasonable. They are the type of farmers who see opportunities, and who are not focused on one commodity. With such a farming model, it is clear that there are times when their income is good and times when it is otherwise. This is similar to the observations of Mahajan (2005) [17], who stated that "savings are particularly important, as these act as self-insurance in case of 
smaller contingencies; meet sudden demands of cash due to illness, for instance; act as margin money or 'equity' for borrowing; and finally, to some extent, act as a collateral for repayment of loans".

On the other hand, other factors that influenced food consumption decisions, but which were indirectly related to the KMP program, were the availability of extra income, the willingness or desire to eat a specific food, curiosity, and specific moments in time, such as religious and cultural celebrations. Good selling prices led to additional earnings, which were influenced by the program. The extra income enabled them to access more food, although the level of food access may differ from one household to another, or from one community to another, as noted in this study. Hence, we can say that the program did not influence farmers' household consumption, except when the selling price of crops was better, as discuss in the next section.

\subsection{The Impact of the Program on Food Security Levels among Small Family Farmers \\ 4.3.1. Food Availability}

All of the communities increased their farm production volume in some commodities. Some were for consumption, and some were sold directly to middleman to obtain the benefit of the sale. Three crops were both consumed and sold: rice, banana, and vegetables. Meanwhile, pepper and oil palm fruits were sold to gain income.

As depicted in Table 8 below, the Ruis hamlet produced 8 tons of bananas annually, of which they consumed only $5 \%$. The farmers increased their rice grain production to 1.5 tons and consumed $90 \%$ of the yield. As for the 80 tons of oil palm fruits and 1.6 tons of pepper, they were sold. As such, they had access to more bananas and rice for consumption. Other food items were accessed using the money obtained from selling oil palm fruits and pepper, as well as the remaining unconsumed bananas and rice. In the Kenaman hamlet, the farmers harvested more than 7 tons of vegetables (of which $2 \%$ was consumed) and 12 tons of rice grain (of which $90 \%$ was consumed) annually. The main non-consumable crop was pepper, of which around $200 \mathrm{~kg}$ was harvested annually. In this case, the farmers had better access to rice and vegetables, and other food items were purchased using the money that they gained from selling pepper. In the Berungkat hamlet, the farmers grew more than 10 tons of rice grain (of which $80 \%$ was consumed) annually. Rice, being their staple food, was more available and accessible to them. At the same time, they sold 2.2 tons of pepper and 131.5 tons of oil palm fruit annually to meet their financial needs, helping them purchase additional food items for family needs.

Table 8. Estimation of additional farming productivity (ton/year) after the implementation of the KMP program.

\begin{tabular}{ccccccc}
\hline \multirow{2}{*}{ No. } & & \multicolumn{4}{c}{ Additional Farming Productivity (Ton/Year) after KMP } \\
\cline { 3 - 7 } & Community & Rice & Vegetables & Bananas & $\begin{array}{c}\text { Oil Palm } \\
\text { Fruit }\end{array}$ & Pepper \\
\hline \multirow{2}{*}{1} & Ruis & 1.5 & - & 8 & 80 & 1.6 \\
& Consumed & $90 \%$ & - & $5 \%$ & - & - \\
\hline 2 & Kenaman & 12 & 7 & - & - & 0.2 \\
& Consumed & $90 \%$ & $2 \%$ & - & - & - \\
\hline 3 & Berungkat & 10 & - & - & 131.5 & 2.2 \\
& Consumed & $80 \%$ & - & - & - & - \\
\hline & Total & 23.5 & 7 & 8 & 211.5 & 4 \\
\hline
\end{tabular}

\subsubsection{Food Access}

The KMP program helped the farmers to increase their income, although food access was not always directly in line with the increase in income. When discussing the impact of 
this income rise on food access, one farmer said, "the income increased when the selling price of agricultural commodities was still reasonable. At least, it was better twice than now. As for food access, it is not directly in line with rise in income. This is because; many needs must be fulfilled, and saving needs in the context of preparation if at any time the selling price of crops declines" (a participant in the FGD in Ruis).

Food access increased when two conditions were present: increased productivity and the reasonable selling price of crops. For instance, when the selling price of their products was reasonable in Ruis between 2015 and 2017, the participating family farmers gained up to $35 \%$ additional access to food. This ratio was around $50 \%$ for farmers in Kenaman and approximately $65 \%$ for farmers in Berungkat. Hence, the KMP program did affect their productivity as they gained more income from selling crops, which led to greater access to food and fulfilled other needs. However, in 2018 and 2019, the drop in the price of pepper badly affected their income. Approximately $71 \%$ of the total respondents confirmed the decrease of the selling price of their crops. On top of that, the prices of necessities had been rising, along with the costs of other needs, such as the costs of supporting children in tertiary level education, where a few years ago they had still lived with their parents. Instead of saving money, they were spending the savings that they had accumulated from several years ago when the prices of latex, palm, and pepper were still reasonable. In particular, from 2015 to 2017, the farmers enjoyed good incomes as the prices of goods were still low and their financial condition was better. Table 9 below shows the changes in the selling prices of cash crops.

Table 9. Selling prices of cash crops.

\begin{tabular}{cccc}
\hline Crops & Volume & $\begin{array}{c}\text { Selling Prices } \\
\text { 2015-2017 (IDR) }\end{array}$ & $\begin{array}{c}\text { Selling Prices } \\
\text { 2018-2019 (IDR) }\end{array}$ \\
\hline Palm oil fruits & $1 \mathrm{~kg}$ & $1200-1400$ & $700-800$ \\
Rubber & $1 \mathrm{~kg}$ & $18,000-20,000$ & $6000-7000$ \\
Pepper & $1 \mathrm{~kg}$ & $100,000-120,000$ & $23,000-25,000$ \\
\hline
\end{tabular}

In contrast, the farmers in the Kenaman hamlet were experiencing an increase in their income even at the time of this study. Since this community focused more on vegetable crops, they earned a more stable income than farmers from other communities. This is because vegetable crops had more stable selling prices than other agricultural commodities in the area.

One noted impact from the KMP program was better food access due to better farming productivity for both sales and self-consumption of rice, vegetables, and bananas. As observed from the field data, the enhanced farming productivity among the farmer groups reflected the positive impact of the loans used by farmers for their farming activities. They gained better access to food crops and received extra income from selling cash crops. The three crops that were both consumed and sold were rice, banana, and vegetables. All of the pepper and oil palm fruits were sold to gain income.

\subsubsection{Food Utilization}

To measure dietary diversity within the communities, the household monthly consumption of seven food groups was assessed based on the standard 14-day measurement explained above. In the Ruis hamlet, the eating patterns at the household level did not change much over five years, except for the quantity. They saved excess money for other needs, especially for their children's school or college needs, rather than for supplementing food. The community maintained the same standard of food. Their consumption was neither excessive nor deficient, but merely sufficient. Therefore, the condition of eating at home, regardless of income level, remained the same. The HDDS before the program in 2015-2016 (when crops had a reasonable selling price) and at the time of this study was 4 (low dietary diversity (DD)) (see Table 10). The HDDS of a non-participant family farmer was also measured and it resulted in a score of 3 (low DD). 
Table 10. Current HDDS of the community in the Ruis hamlet.

\begin{tabular}{|c|c|c|c|c|c|}
\hline Food Groups & $\begin{array}{l}\text { Food Groups } \\
\text { Used }\end{array}$ & $\begin{array}{l}\text { Staple Food Ingredients } \\
\text { (First List of All } \\
\text { Food Items) }\end{array}$ & $\begin{array}{l}\text { Proportion of } \\
\text { Monthly Food } \\
\text { Consumption } \\
\text { (Days/Month) }\end{array}$ & $\begin{array}{l}\text { Weight for } \\
\text { HDDS }\end{array}$ & $\begin{array}{l}\text { HDDS } \\
\text { (Consumed More } \\
\text { Than } 14 \text { Days) }\end{array}$ \\
\hline $\begin{array}{l}\text { 1. Cereals, roots, } \\
\text { and tubers }\end{array}$ & Cereal and grain & $\begin{array}{l}\text { 1. Rice } \\
\text { 2. Cassava }\end{array}$ & $\begin{array}{l}1.45 \mathrm{~kg} \\
2.5 .2 \mathrm{~kg}\end{array}$ & $0 / 1$ & 1 \\
\hline $\begin{array}{l}\text { 2. Pulses and } \\
\text { legumes }\end{array}$ & Legumes/nuts & $\begin{array}{l}\text { 1. Long beans } \\
\text { 2. Tempeh and tofu }\end{array}$ & $\begin{array}{l}\text { 1. } 2 \text { days } \\
\text { 2. } 5 \text { days }\end{array}$ & $0 / 1$ & 0 \\
\hline 3. Vegetables & $\begin{array}{l}\text { Orange vegetables } \\
\text { (rich in vitamin A) } \\
\text { Green leafy } \\
\text { vegetables } \\
\text { Other vegetables }\end{array}$ & $\begin{array}{l}\text { 1. Cassava leaves } \\
\text { 2. Bamboo shoots } \\
\text { 3. Ferns } \\
\text { 4. Kangkong } \\
\text { 5. Banana blossom } \\
\text { 6. Mustard green } \\
\text { 7. Spinach } \\
\text { 8. Aubergine } \\
\text { 9. Pumpkins leaves } \\
\text { 10. Cucumber leaves }\end{array}$ & 30 days & $0 / 1$ & 1 \\
\hline 4. Fruits & $\begin{array}{l}\text { Orange fruits (rich } \\
\text { in vitamin A) } \\
\text { Other fruits }\end{array}$ & $\begin{array}{l}\text { 1. Banana } \\
\text { 2. Orange } \\
\text { 3. Longan }\end{array}$ & $\begin{array}{l}\text { 1. } 4 \text { days } \\
\text { 2. } 2 \text { days } \\
\text { 3. } 1 \text { day }\end{array}$ & $0 / 1$ & 0 \\
\hline $\begin{array}{l}\text { 5. Meats, fish and } \\
\text { seafood, and eggs }\end{array}$ & $\begin{array}{l}\text { Meat } \\
\text { Liver, kidney, heart } \\
\text { and other organ } \\
\text { meats } \\
\text { Fish/shellfish } \\
\text { Eggs }\end{array}$ & $\begin{array}{l}\text { 1. Meat } \\
\text { 2. Fish } \\
\text { 3. Eggs }\end{array}$ & $\begin{array}{l}\text { 1. } 5 \text { days } \\
\text { 2. } 6 \text { days } \\
\text { 3. } 23 \text { days }\end{array}$ & $0 / 1$ & 1 \\
\hline 6. Dairy products & $\begin{array}{l}\text { Milk and other } \\
\text { dairy products }\end{array}$ & Milk & $0.7 \mathrm{~kg}$ & $0 / 1$ & 0 \\
\hline 7. Oils and fats & Oil/fat/butter & Cooking oil & $2.8 \mathrm{~kg}$ & $0 / 1$ & 1 \\
\hline \multicolumn{5}{|c|}{ Total HDDS } & 4 \\
\hline
\end{tabular}

In the Berungkat hamlet, the farmers there were also affected by the low selling prices of farm commodities. The crops included pepper, oil palm, rubber plant, and rice. The good selling price period in 2015-2017 helped them gain better access to food and to consume a more diverse range of food. At that time, they consumed more fruits than the other communities, meaning their HDDS was 5 (medium DD). The two non-participant family farmers in this community scored 6 and 5 (medium DD) for their HDDS due to their better family condition and farming activities than the participant family farmers in this hamlet. Table 11 below shows the current HDDS of the community in the Berungkat hamlet.

The last community is the Kenaman hamlet. In this hamlet, the dietary diversity was better because they consumed more legumes and nuts. Their dietary diversity was better after the program due to two factors: first, most of them were not native people (they came to this place looking for a better opportunity for their life), and second, they cultivated rice and vegetable crops, which had a more stable price at that time. As for dietary diversity, they had a better score compared to other communities because they consumed more legumes and nuts. The current HDDS in this community is 5 (medium DD) (see Table 12 below), while the HDDS before the program was 4 (low DD). Meanwhile, a non-participant family farmer in this community scored 4 (low DD). 
Table 11. Current HDDS of the community in the Berungkat hamlet.

\begin{tabular}{|c|c|c|c|c|c|}
\hline Food Groups & Food Groups Used & $\begin{array}{l}\text { Staple Food } \\
\text { Ingredients (First } \\
\text { List of All } \\
\text { Food Items) }\end{array}$ & $\begin{array}{l}\text { Proportion of } \\
\text { Monthly Food } \\
\text { Consumption } \\
\text { (Days/Month) }\end{array}$ & $\begin{array}{l}\text { Weight for } \\
\text { HDDS }\end{array}$ & $\begin{array}{l}\text { HDDS } \\
\text { (Consumed More } \\
\text { Than } 14 \text { Days) }\end{array}$ \\
\hline $\begin{array}{l}\text { 1. Cereals, roots, } \\
\text { and tubers }\end{array}$ & Cereal and grain & $\begin{array}{l}\text { 1. Rice } \\
\text { 2. Cassava } \\
\text { 3. Sweat potatoes }\end{array}$ & $\begin{array}{l}\text { 1. } 31.5 \mathrm{~kg} \\
\text { 2. } 6 \mathrm{~kg} \\
\text { 3. } 2 \mathrm{~kg}\end{array}$ & $0 / 1$ & 1 \\
\hline $\begin{array}{l}\text { 2. Pulses and } \\
\text { legumes }\end{array}$ & Legumes/nuts & 1. Long beans & 1 day & $0 / 1$ & 0 \\
\hline 3. Vegetables & $\begin{array}{l}\text { Orange vegetables (rich in } \\
\text { vitamin A) } \\
\text { Green leafy vegetables } \\
\text { Other vegetables }\end{array}$ & $\begin{array}{l}\text { 1. Cassava leaves } \\
\text { 2. Bamboo shoots } \\
\text { 3. Ferns } \\
\text { 4. Cucumber } \\
\text { leaves } \\
\text { 5. Pumpkins } \\
\text { 6. Pumpkins leave } \\
\text { 7. Katuk } \\
\text { 8. Kangkong }\end{array}$ & $\begin{array}{l}\text { Every day, always } \\
\text { consume } \\
\text { vegetables with } \\
\text { different types of } \\
\text { vegetables }\end{array}$ & $0 / 1$ & 1 \\
\hline 4. Fruits & $\begin{array}{l}\text { Orange fruits (rich in } \\
\text { vitamin A) } \\
\text { Other fruits }\end{array}$ & $\begin{array}{l}\text { 1. Banana } \\
\text { 2. Orange } \\
\text { 3. Watermelon } \\
\text { 4. Pineapple }\end{array}$ & $\begin{array}{l}\text { 1. } 5 \text { days } \\
\text { 2. } 2 \text { days } \\
\text { 3. } 2 \text { days } \\
\text { 4. } 2 \text { days }\end{array}$ & $0 / 1$ & 0 \\
\hline $\begin{array}{l}\text { 5. Meats, fish and } \\
\text { seafood, and eggs }\end{array}$ & $\begin{array}{l}\text { Meat } \\
\text { Liver, kidney, heart and } \\
\text { other organ meats } \\
\text { Fish/shellfish } \\
\text { Eggs }\end{array}$ & $\begin{array}{l}\text { 1. Meat } \\
\text { 2. Fish } \\
\text { 3. Eggs }\end{array}$ & $\begin{array}{l}\text { 1. } 6 \text { days } \\
\text { 2. } 7 \text { days } \\
\text { 3. } 22 \text { days }\end{array}$ & $0 / 1$ & 1 \\
\hline 6. Dairy products & $\begin{array}{l}\text { Milk and other dairy } \\
\text { products }\end{array}$ & 1. Milk & $\begin{array}{l}0.2 \mathrm{~kg} \\
\text { daily only for } \\
\text { toddlers }\end{array}$ & $0 / 1$ & 0 \\
\hline 7. Oils and fats & Oil/fat/butter & Cooking oil & $3.5 \mathrm{~kg}$ & $0 / 1$ & 1 \\
\hline \multicolumn{5}{|c|}{ Total HDDS } & 4 \\
\hline
\end{tabular}

Table 12. Current HDDS of the community in the Kenaman hamlet.

\begin{tabular}{|c|c|c|c|c|c|}
\hline Food Groups & Food Groups Used & $\begin{array}{l}\text { Staple Food } \\
\text { Ingredients (First } \\
\text { List of All } \\
\text { Food Items) }\end{array}$ & $\begin{array}{l}\text { Proportion of } \\
\text { Monthly Food } \\
\text { Consumption } \\
\text { (Days/Month) }\end{array}$ & $\begin{array}{l}\text { Weight for } \\
\text { HDDS }\end{array}$ & $\begin{array}{l}\text { HDDS } \\
\text { (Consumed More } \\
\text { Than } 14 \text { Days) }\end{array}$ \\
\hline $\begin{array}{l}\text { 1. Cereals, roots, } \\
\text { and tubers }\end{array}$ & Cereal and grain & $\begin{array}{l}\text { 1. Rice } \\
\text { 2. Cassava }\end{array}$ & $\begin{array}{l}\text { 1. } 37.5 \mathrm{~kg} \\
2.3 .8 \mathrm{~kg}\end{array}$ & $0 / 1$ & 1 \\
\hline $\begin{array}{l}\text { 2. Pulses and } \\
\text { legumes }\end{array}$ & Legumes/nuts & $\begin{array}{l}\text { 1. Tempeh and } \\
\text { tofu } \\
\text { 2. Long beans } \\
\text { 3. Soybean }\end{array}$ & $\begin{array}{l}\text { 1. } 10 \text { days } \\
\text { 2. } 5 \text { days } \\
\text { 3. } 1 \text { day }\end{array}$ & $0 / 1$ & 1 \\
\hline 3. Vegetables & $\begin{array}{l}\text { Orange vegetables (rich in } \\
\text { vitamin A) } \\
\text { Green leafy vegetables } \\
\text { Other vegetables }\end{array}$ & $\begin{array}{l}\text { 1. Cassava leaves } \\
\text { 2. Bamboo shoots } \\
\text { 3. Ferns } \\
\text { 4. Mustard green } \\
\text { 5. Spinach } \\
\text { 6. Cabbage } \\
\text { 7. Kangkong }\end{array}$ & 25 days & $0 / 1$ & 1 \\
\hline
\end{tabular}


Table 12. Cont.

\begin{tabular}{|c|c|c|c|c|c|}
\hline Food Groups & Food Groups Used & $\begin{array}{l}\text { Staple Food } \\
\text { Ingredients (First } \\
\text { List of All } \\
\text { Food Items) }\end{array}$ & $\begin{array}{l}\text { Proportion of } \\
\text { Monthly Food } \\
\text { Consumption } \\
\text { (Days/Month) }\end{array}$ & $\begin{array}{l}\text { Weight for } \\
\text { HDDS }\end{array}$ & $\begin{array}{l}\text { HDDS } \\
\text { (Consumed More } \\
\text { Than } 14 \text { Days) }\end{array}$ \\
\hline 4. Fruits & $\begin{array}{l}\text { Orange fruits (rich in } \\
\text { vitamin A) } \\
\text { Other fruits }\end{array}$ & $\begin{array}{l}\text { 1. Banana } \\
\text { 2. Papaya } \\
\text { 3. Guava } \\
\text { 4. Orange } \\
\text { 5. Zalacca } \\
\text { 6. Watermelon }\end{array}$ & $\begin{array}{l}\text { 1. } 4 \text { days } \\
\text { 2. } 2 \text { days } \\
\text { 3. } 3 \text { days } \\
\text { 4. } 2 \text { days } \\
\text { 5. } 0.2 \text { day } \\
\text { 6. } 0.2 \text { day }\end{array}$ & $0 / 1$ & 0 \\
\hline $\begin{array}{l}\text { 5. Meats, fish and } \\
\text { seafood, and eggs }\end{array}$ & $\begin{array}{l}\text { Meat } \\
\text { Liver, kidney, heart and } \\
\text { other organ meats } \\
\text { Fish/shellfish } \\
\text { Eggs }\end{array}$ & $\begin{array}{l}\text { 1. Meat } \\
\text { 2. Fish } \\
\text { 3. Eggs }\end{array}$ & $\begin{array}{l}\text { 1. } 3 \text { days } \\
\text { 2. } 3 \text { days } \\
\text { 3. } 12 \text { days }\end{array}$ & $0 / 1$ & 1 \\
\hline 6. Dairy products & $\begin{array}{l}\text { Milk and other dairy } \\
\text { products }\end{array}$ & Milk & $\begin{array}{l}-0.7 \mathrm{~kg} \\
\text { - Milk for baby }\end{array}$ & $0 / 1$ & 0 \\
\hline 7. Oils and fats & Oil/fat/butter & Cooking oil & $3.1 \mathrm{~kg}$ & $0 / 1$ & 1 \\
\hline \multicolumn{5}{|c|}{ Total HDDS } & 5 \\
\hline
\end{tabular}

Table 13 below lists the HDDS of each hamlet before the program, during the program when the crops' selling prices were reasonable (2015-2017), and after 2017 when government support ended.

Table 13. Household dietary diversity score before and after KMP program.

\begin{tabular}{|c|c|c|c|c|c|}
\hline \multirow{2}{*}{ No. } & \multirow{2}{*}{ Community } & \multicolumn{3}{|c|}{ HDDS } & \multirow[t]{2}{*}{ Note } \\
\hline & & Before & 2015-2017 & After 2017 & \\
\hline 1 & Ruis & 4 & 4 & 4 (non: 3 ) & $<4.5=$ Low dietary diversity \\
\hline 2 & Berungkat & 4 & 5 & 4 (non: 5 ) & $4.5-6.0=$ Medium dietary diversity \\
\hline 3 & Kenaman & 4 & 5 & 5 (non: 4 ) & $>6.0=$ High $/$ good dietary diversity \\
\hline
\end{tabular}

\section{Conclusions}

The regulations issued for this program stipulated that DMP is meant for one community in a regular region, while KMP is dedicated to several communities in a region. It was found that the KMP model did not succeed, as discovered with the Karir group. Some obstacles were identified, including the distance between hamlets, a lack of control, a lack of trust among groups, low management capability, and low commitment. The DMP model with the Sumber Rejeki group was very successful because it targeted only one group in one community. They knew and trusted each other. Other factors included the good capability of the management and the good commitment of the members. Moreover, the microloan program in this group was used not only to help farmers increase their farming production, but also to meet many needs, such as education costs for children, helping with healthcare, contributing to family savings, and improving assets. Thus, this program should be continued in future within the DMP model, where one LKK (local financial institution) is only for one community.

One solution for the LKKs in Karir is where the loan is collected by each subgroup. In this way, each subgroup can roll out the loan only among their members in the future, while they (the sub-management) can regularly send reports of their activities to the management. This stands in contrast to the LKK in Sumber Rejeki, where the management assessed the commitment and capability of their members to repay the loan. This policy would undeniably have a good impact on program sustainability, but it would exclude the very 
poor. Therefore, it is crucial to provide a specific service to the very poor, and support not only the program members, but also any other person from their community.

The rise in income did not lead farmers to purchase more nutritious food for consumption. Rather, the increased income motivated farmers to fulfil many needs, such as education costs for their children, farm inputs, healthcare, and asset improvement. However, the farmers in this study constantly faced difficulties due to climate conditions and volatility in the selling price of crops, which then motivated the farmers to save their money to prepare for uncertain times. Thus, ensuring sufficient food security for their family was not a priority for them. Hence, the government should use the food security measurement to assess food security at the household level among the participant farmers as they exit the program.

As revealed in this study, the income of the farmers decreased when the price of crops dropped despite increases in yields due to the financial access that they gained from the program. This prevented them from accessing farming inputs, thus harming their farms' productivity. Therefore, in order to prevent price volatility with agricultural commodities, the government could install a locally owned enterprise that would buy their agricultural products. This may be a viable solution to provide a market for small family farmers. At the same time, this enterprise must provide and sell everything that farmers need, such as fertilizers, herbicides, pesticides, as well as agricultural, fishery, and livestock-related equipment. With the provision of a good monitoring system, appropriate trainees, adequate financial support to buy goods, conduct supervision, and transparent audits, the proposed enterprise may be able to maintain or even increase the income of the farmers.

\section{Study Limitation}

First, this study lacks a discussion on the sociological aspects of MFI, such as social action, culture, motives, and values (religion and ethics), which could influence one's behavior. This also includes a lack of supportive institutions and grassroots participation. Research to evaluate the KMP program, inclusive of sociological dimensions, is integral to gain a more comprehensive understanding and to help develop a better formulated and more innovative financial aid program for the local small family farms and the local community. Second, this study did not explore the role of local government agencies and agricultural extension workers in the Sekayam subdistrict, who act as supervisors in deploying the programs. A study that assesses the importance of the implementation of cross-sector coordination, synchronization, and integration for rural infrastructure development across local government agencies and agricultural extension workers, who support the programs by administering technical and managerial training, supervision, additional budget support (if any), infrastructure support, or other types of support outlined in the expected outcomes of the KMP program, could be substantial. A study on the multi-level governance that is required when implementing the program for small family farms could also be interesting. More work should look into the role of each level of the government to explain the smooth implementation of the program, and then formulate a better investment program framework that fits all government levels to provide better support to small family farms for achieving better local food security.

Author Contributions: Author contributions consist of (1) writing the first draft by E.P.; (2) conception and design of the work by E.P. and G.B.; (3) sources by E.P., G.B. and P.P.; (4) methodology by E.P. and G.B.; (5) analysis by E.P.; (6) supervision by G.B. and P.P.; (7) editing and adding text by E.P., G.B. and P.P. All authors have read and agreed to the published version of the manuscript.

Funding: This work was supported and funded by Lembaga Pengelola Dana Pendidikan (LPDP), Ministry of Finance, Republic of Indonesia. LPDP funding number: 201711221011886.

Conflicts of Interest: The authors at this moment declare that there are no conflict of interest. 


\section{References}

1. Obaidullah, M. Enhancing food security with Islamic microfinance: Insights from some recent experiments. Agric. Financ. Rev. 2015, 75, 142-168. [CrossRef]

2. BPS-Statistic Indonesia. Statistical Yearbook of Indonesia 2019; BPS: Jakarta, Indonesia, 2019; ISSN 0126-2912. Available online: https:/ / www.bps.go.id/publication/2019/07/04/daac1ba18cae1e90706ee58a/statistik-indonesia-2019.html (accessed on 26 January 2020).

3. FAO. Smallholders Data Portrait. 2018. Available online: www.fao.org/family-farming/data-sources/dataportrait/farm-size/en (accessed on 26 February 2019).

4. Hidayat, K.; Nugraha, J.P. The Food Self-reliance Rural Action Program (The Process Implementation and Impact on Socioeconomic Conditions of Poor Households in Tamanasri Village, Pacitan District). HABITAT 2013, 22, 84-97. Available online: https:/ / habitat.ub.ac.id/index.php/habitat/article/view/120 (accessed on 27 January 2020).

5. Baihaqi, A. Dampak Program Desa Mandiri Pangan Terhadap Ketahanan Pangan Dan Kemiskinan Di Kabupaten Aceh Timur. J. Agrisep 2013, 14, 12-20. Available online: http:/ / www.jurnal.unsyiah.ac.id/agrisep/article/view / 2370 (accessed on 27 January 2020).

6. Darwis, V.; Supriyati dan Rusastra, I.W. Dampak Program Desa Mandiri Pangan Terhadap Ketahanan Pangan Dan Kemiskinan. Inform. Pertan. 2014, 23, 47-58. Available online: http://repository.pertanian.go.id/handle/123456789/1106 (accessed on 26 January 2020). [CrossRef]

7. Bidisha, S.H.; Khan, A.; Imran, K.; Khondker, B.H.; Suhrawardy, G.M. Role of credit in food security and dietary diversity in Bangladesh. Econ. Anal. Policy 2017, 53, 33-45. [CrossRef]

8. Meador, J.; Fritz, A. Food Security in Rural Uganda: Assessing Latent Effects of Microfinance on Pre-Participation. Dev. Pract. 2017, 27, 340-353. [CrossRef]

9. Adnan Shahid, M.; Bohara, A. Does Microfinance Increase Food Security? Evidence from Nepal. J. Food Secur. 2020, 8, 89-97. [CrossRef]

10. World Bank. Indonesia Overview. 2016. Available online: http://www.worldbank.org/en/country/indonesia/overview (accessed on 26 February 2019).

11. Robinson, M.S. The Microfinance Revolution: Lessons from Indonesia; World Bank Publications: Washington, DC, USA, 2002.

12. Morris, G.; Barnes, C. An assessment of the impact of microfinance: A case study from Uganda. J. Microfinance/ESR Rev. 2005, 7, 4. Available online: https:/ / scholarsarchive.byu.edu/esr/vol7/iss1/4 (accessed on 27 May 2020).

13. Karmakar, K.G. Microfinance revisited. In Microfinance in India; SAGE Publications: Thousand Oaks, CA, USA, 2008 ; pp. 33-54.

14. Mahajan, V. From Microcredit to Livelihood Finance. Econ. Political Wkly. 2005, 40, 4416-4419. Available online: http://www. jstor.org/stable/4417256 (accessed on 27 May 2020).

15. Finnis, E. Why Grow Cash Crops? Subsistence Farming and Crop Commercialization in the Kolli Hills, South India. Am. Anthropol. 2006, 108, 363-369. [CrossRef]

16. Baker, K. Drought, Agriculture and Environment: A Case Study from the Gambia, West Africa. Afr. Aff. 1995, 94, 67-86. Available online: http:/ / www.jstor.org/stable/723914 (accessed on 27 January 2020). [CrossRef]

17. Rigg, J. Forces and Influences behind the Development of Upland Cash Cropping in North-East Thailand. Geogr. J. 1987, 153, 370. [CrossRef]

18. Desmarais, A.A. PEASANTS SPEAK-The Vía Campesina: Consolidating an International Peasant and Farm Movement. J. Peasant. Stud. 2002, 29, 91-124. [CrossRef]

19. Nigh, R. Organic Agriculture and Globalization: A Maya Associative Corporation in Chiapas, Mexico. Hum. Organ. 1997, 56, 427-436. Available online: http:/ / www.jstor.org/stable/44127880 (accessed on 27 May 2020). [CrossRef]

20. Watts, M.J.; Bassett, T.J. Crisis and Change in African Agriculture: A Comparative Study of the Ivory Coast and Nigeria. Afr. Stud. Rev. 1985, 28, 3. [CrossRef]

21. Henrich, J. Market Incorporation, Agricultural Change, and Sustainability among the Machiguenga Indians of the Peruvian Amazon. Hum. Ecol. 1997, 25, 319-351. [CrossRef]

22. Attwood, D.W. Raising Cane: The Political Economy of Sugar in Western India; Westview Press: Boulder, CO, USA, 1992.

23. Adams, W.; Mortimore, M. Agricultural Intensification and Flexibility in the Nigerian Sahel. Geogr. J. 1997, 163, 150. [CrossRef]

24. Neuman, W. Lawrence. Social Research Methods: Qualitative and Quantitative Approaches, 6th ed.; Pearson Education, Inc.: New York, NY, USA, 2006.

25. Swindale, A.; Bilinsky, P. Household Dietary Diversity Score (HDDS) for Measurement of Household Food Access: Indicator Guide (v.2); FHI 360/FANTA: Washington, DC, USA, 2006; Available online: https://www.fantaproject.org/sites/default/files/resources/ HDDS_v2_Sep06_0.pdf (accessed on 26 February 2019).

26. Jackson, E.T. Interrogating the theory of change: Evaluating impact investing where it matters most. J. Sustain. Financ. Invest. 2013, 3, 95-110. [CrossRef]

27. Davies, R.; Dart, J. The 'Most Significant Change' Technique: A Guide to Its Use; Cambridge, UK, 2005. Available online: https:// www.wikifplan.org/WIKIPLAN/1\%201\%20151\%20-\%20Most_significant_change_methodology_pa_abril\%202005.pdf (accessed on 16 March 2020).

28. Funnell, S.C.; Rogers, P.J. Purposeful Program Theory: Effective Use of Theories of Change and Logic Models; Jossey-Bass: San Francisco, CA, USA, 2011. 
29. Morra-Imas, L.; Rist, C. The Road to Results: Designing and Conducting Effective Development Evaluations; World Bank: Washington, DC, USA, 2009.

30. Rogers, P.J. Using Programme Theory to Evaluate Complicated and Complex Programmes. Evaluation 2008, 14, 29-48. [CrossRef]

31. Stein, D.; Valters, C. Understanding Theory of Change in International Development. (JSRP and TAF Collaborative Project) (JSRP Paper 1); Justice and Security Research Programme, International Development Department, London School of Economics and Political Science: London, UK, 2012.

32. Adekunle, A.A.; Fatunbi, A.O. A New Theory of Change in African Agriculture. Middle-East J. Sci. Res. 2014, $21,1083-1096$. [CrossRef]

33. Mayne, J.; Johnson, N. Using theories of change in the CGIAR Research Program on Agriculture for Nutrition and Health. SAGE 2015, 21, 407-428. [CrossRef]

34. De Silva, M.J.; Breuer, E.; Lee, L.; Asher, L.; Chowdhary, N.; Lund, C.; Patel, V. Theory of Change: A theory-driven approach to enhance the Medical Research Council's framework for complex interventions. Trials 2014, 15, 5. [CrossRef] [PubMed]

35. Schierhout, G.; Hains, J.; Si, D.; Kennedy, C.; Cox, R.; Kwedza, R.; O’Donoghue, L.; Fittock, M.; Brands, J.; Lonergan, K.; et al. Evaluating the effectiveness of a multifaceted, multilevel continuous quality improvement program in primary health care: Developing a realist theory of change. Implement. Sci. 2013, 8, 119. [CrossRef] [PubMed]

36. Fullan, M. Change Theory as a Force for School Improvement. In Intelligent Leadership; Springer: Dordrecht, The Netherlands, 2007; pp. 27-39. [CrossRef] 